 \\ z Filologii Polskiej i Słowiańskiej
}

\section{Międzynarodowa konferencja naukowa Мови Європи в стані оновлення (Kijów, 20-21 kwietnia 2016)}

W dniach 20-21 kwietnia 2016 r. odbyło się w Kijowie na Ukrainie międzynarodowe seminarium naukowe Мови Європи в стані оновлення. Spotkanie zostało zorganizowane przez członków zakładu lingwistyki strukturalno-matematycznej Instytutu Języka Ukraińskiego NANU w ramach międzynarodowego projektu badawczego Лексичні, словотвірні та фразеологічні інновації в сучасних слов'янських мовах. Koordynatorem projektu po stronie ukraińskiej jest prof. E. A. Karpilovs'ka, a po stronie polskiej - dr Z. Rudnik-Karwatowa $z$ Instytutu Slawistyki PAN. W ciągu dwóch dni prelegenci wygłosili trzydzieści cztery referaty w czterech językach słowiańskich (ukraińskim, białoruskim, rosyjskim i polskim). Konferencję otworzył dyrektor Instytutu Języka Ukraińskiego NANU prof. P. Ju. Gricenko. Referaty wpisywały się w wieloaspektową problematykę dotyczącą tendencji, procesów i zjawisk występujących we współczesnych językach słowiańskich (ukraińskim, białoruskim, rosyjskim, polskim, słowackim, czeskim, bułgarskim i słoweńskim) 
oraz języku nowogreckim. Jak wiadomo, sytuacja języków słowiańskich na przełomie wieków zmienia się niezwykle dynamiczne. Z jednej strony obecne są tendencje, które zarysowały się w okresie wcześniejszym (po drugiej wojnie światowej), z drugiej natomiast widoczny jest wpływ późniejszych przemian geopolitycznych takich jak upadek komunizmu, rozpad Jugosławii itp., które zintensyfikowały szereg procesów rozwojowych w obszarze słowiańskim. Wśród głównych tendencji językowych, które zostały omówione w referatach, wymienić należy tendencję do internacjonalizacji, demokratyzacji oraz różnego rodzaju zmiany typologiczne w obrębie leksyki i słowotwórstwa. Zmieniająca się sytuacja językowa różnicuje jednak poszczególne języki słowiańskie, co znalazło swój wyraz w przedstawionych referatach.

Szczególnie dużo miejsca poświęcono innowacjom językowym, wskazując na ich społeczne i kulturowe uwarunkowania oraz potrzeby komunikacyjne użytkowników języka. Prof. E. A. Karpilovs'ka przedstawiła w referacie kryteria określające stabilność innowacji językowych, wśród których wyróżniła następujące czynniki: długotrwałość funkcjonowania innowacji, siłę potencjału funkcjonalnego (syntagmatycznego, paradygmatycznego i słowotwórczego) danej jednostki, potrzebę nominacyjną oraz szerokie możliwości dostosowania danej formy wyrazowej do różnych sub-norm i potrzeb komunikacyjnych. Problematyka związana $z$ adaptacją i standaryzacją nowych jednostek języka znalazła wyraz w licznych pracach poświęconych językowi ukraińskiemu. Dr Ju. V. Romanjuk zwróciła uwagę na ważną rolę analogii w obrębie innowacji czasownikowych. Dr L. P. Kisljuk w swoim wystąpieniu omówiła aktywizację różnych elementów słowotwórczych pochodzenia obcego w języku ukraińskim oraz tendencje analityczne w obrębie kompozytów.

Wśród innych wystąpień wyróżnić można grupę poświęconą derywacji semantycznej. Dr P. Kowalski zwrócił uwagę na niezwykle istotną kwestię relacji zachodzących pomiędzy różnymi metodologicznie ujęciami omawianej problematyki (derywat semantyczny vs neosemantyzm vs neologizm semantyczny) oraz drugą stronę procesu - paleosemantyzację.

Szereg referatów poświęcono terminologii z zakresu różnych dziedzin (od informatyki i językoznawstwa po pszczelarstwo). Dr I. Łuczków omówiła rolę tradycji jako czynnika hamującego innowacje terminologiczne. Dr Z. Rudnik-Karwatowa przedstawiła pozajęzykowe czynniki kształtujące powstawanie nowych terminów językoznawczych na przykładzie konkurencji form typu lingwokulturologia vs lingwistyka kulturowa. Dr Ja. Volkava w swoim referacie poświęconym terminologii prawnej i prawniczej w języku białoruskim zauwa- 
żyła, że język ten podlegał naturalnym procesom terminotwórczym do końca XVII w., jednak od XX w. do chwili obecnej sytuacja przedstawia się zgoła odmiennie. Zasób terminologiczny jest bowiem poszerzany poprzez przekład istniejących terminów rosyjskich.

Dr M. Fastyn zaprezentował w referacie znaczące (przejrzyste słowotwórczo) nazwy własne osobowe w „Bajkach robotów” S. Lema oraz ich przekłady na język bułgarski, rosyjski i czeski.

Seminarium cieszyło się bardzo dużym zainteresowaniem po stronie ukraińskiej i w sposób znaczny wykroczyło poza ramy pierwotnie planowanego spotkania roboczego uczestników międzynarodowego projektu badawczego Лексичні, словотвірні та фразеологічні інновачії в сучасних слов'янських мовах. Całe spotkanie przebiegało w bardzo miłej atmosferze. W dyskusji zaproponowano, aby zorganizować kolejne sesje $\mathrm{w}$ tym formacie, co pozwala mieć nadzieję, że konferencja nabierze cyklicznego charakteru. Referaty zostaną opublikowane w czasopiśmie Украӥнська мова: науково-теоретичний журнал oraz innych wydawnictwach Instytutu Języka Ukraińskiego NANU.

\section{International scientific conference Мови Європи в стані оновлення (Kiev, 20-21 April 2016)}

\section{Summary}

The article is a report from an international scientific conference, organised on 20-21 April 2016 in Kiev by the Institute of the Ukrainian Language, National Academy of Sciences of Ukraine. The conference, entitled Moвu Європи в стані оновлення, was devoted to innovations in European languages, including especially the Slavic languages. 


\section{Międzynarodowa konferencja naukowa Мови Європи в стані оновлення (Kijów, 20-21 kwietnia 2016)}

\section{Streszczenie}

Artykuł stanowi relację z międzynarodowej konferencji naukowej zorganizowanej w dniach 20-21 kwietnia 2016 roku w Kijowie przez Instytut Języka Ukraińskiego Narodowej Akademii Nauk Ukrainy. Konferencja, zatytułowana Мови Європи в стані оновлення, poświęcona była innowacjom w językach Europy, ze szczególnym uwzględnieniem języków słowiańskich.

Keywords: report; academic life; scientific conference; European languages; Institute of the Ukrainian Language, National Academy of Sciences of Ukraine; Slavic languages; language innovation; lexis; phraseology; word formation

Słowa kluczowe: sprawozdanie; życie naukowe; konferencja naukowa; języki europejskie; Instytut Języka Ukraińskiego Narodowej Akademii Nauk Ukrainy; języki słowiańskie; innowacja językowa; leksyka; frazeologia; słowotwórstwo

Jakub Banasiak, Institute of Slavic Studies, Polish Academy of Sciences, Warsaw

Correspondence: jakubbanasiak@o2.pl

The work was self-funded by the author.

Competing interests: The author has declared he has no competing interests. 